Original Research Paper

\title{
Characterization of Fungal Communities in Limed and Unlimed Lands Contaminated with Metals: Phospholipid Fatty Acid (PLFA) Analysis and Soil Respiration
}

\author{
${ }^{1}$ Kassandre Goupil, ${ }^{1,2}$ Kabwe K. Nkongolo and ${ }^{1}$ Sabah Nasserulla \\ ${ }^{l}$ Department of Biology, \\ ${ }^{2}$ Biomolecular Sciences Program, \\ Laurentian University, Sudbury, Ontario, P3E 2C6, Canada
}

Article history

Received: 05-04-2015

Revised: 28-04-2015

Accepted: 13-05-2015

Corresponding Author: Kabwe K. Nkongolo

Department of Biology,

Laurentian University,

Sudbury, Ontario, P3E 2C6,

Canada

Email: knkongolo@laurentian.ca

\begin{abstract}
Northern Ontario (Canada) especially the Greater Sudbury region is highly known for its nickel, copper and other metal deposits. The mining, roasting and smelting of these elements have caused disastrous effects on the vegetation and overall environment. Dolomitic lime which contains calcium and magnesium carbonate was applied to soils from 1980 to 1995 at different locations across Northern Ontario. The objective of the present study is to determine fungi diversity and abundance in selected limed and unlimed areas contaminated with metals in the Region. Soil respiration, fungi cultures and Phospholipid Fatty Acid (PLFA) were analyzed. The liming did maintain an increase in soil $\mathrm{pH}$ from extremely acid to slightly acid, even 25 to 30 years after liming applications. A total of 52 fungi species belonging to 34 genera were identified on growth media. The majority of fungi (up to $70 \%$ ) in all the sites belong to the Ascomycota phylum. Some species were specific to one or two sites, while others were present in the majority of the sites. Fungal diversity and abundance were higher in limed soils compared to unlimed samples based on SDA medium growth. The rates of soil respiration in limed sites were also higher compared to unlimed areas. Phospholipid Fatty Acid (PLFA) analysis revealed a significantly higher total microbial biomass in samples from limed areas compared to unlimed samples. Total and arbuscular mycorrhizal fungi abundance based on this analysis followed the same trend. Surprisingly, there were 7 to 10 fold more bacteria than fungi in all the sites. Moreover, there was twice more Gram (-) bacteria than Gram $(+)$ indicating that the sites are still severely stressed. Soil $\mathrm{pH}$ appears to be the most important factor for microbial abundance, diversity and activities than total metal content.
\end{abstract}

Keywords: Soil Liming, Fungi Diversity and Abundance, Phospholipid Fatty Acid, Soil Respiration, Northern Ontario

\section{Introduction}

Mining and smelting processes and activities have caused a variety of negative effects to the Northern Ontario environment. $\mathrm{SO}_{2}$ fumigation and the accumulation of numerous metal particulates have damaged soil quality and ultimately, the vegetation and fungi populations inhabiting the region (Winterhalder, 1996). Balsillie et al. (1978) have documented a decrease in soil fungi and bacteria near the location of smelter sites within the Greater Sudbury Region. They also reported a decrease of the levels of colonization of roots of oxeye daisy (Chrysanthemum leucanthemum) and devil's paintbrush (Hieracium aurantiacum) by vesicular arbuscular mycorrhizal fungi in the Sudbury barrens (Balsillie et al., 1978).

A decrease in industrial emissions and remediation projects were initiated to restore Northern Ontario ecosystems (Winterhalder, 1996; Nkongolo et al., 2013; Theriault et al., 2013). Remediation consisted of neutralizing soil $\mathrm{pH}$ with the addition of lime as well as adding fertilizer, seed distribution and tree planting 
(Winterhalder, 1996). In fact, dolomitic lime which contains calcium and magnesium carbonate was applied to soils from 1980 to 1995 at different locations across Northern Ontario. This resulted in an increase of organic matter that requires adequate microbial biomass for mineralization's processes. The intricacies of soil-fungal interactions are crucial in determining fungi diversity and abundance for a particular region. Thus, soil chemistry, metal binding capacity and metal speciation within the soil are key concepts that need to be adequately assessed and properly understood in order to sufficiently identify metal-fungal dynamics for a specific region. The examination of fungal diversity for a particular area is critical as it is an essential factor in the determination of their sustainability (Nielsen and Winding, 2002). Additionally, fungal abundance is another prime indicator of their population health (Nielsen and Winding, 2002). Since fungi play such a crucial role in soil formation, organic matter decomposition as well as in the transformations of toxic metabolites found in the soil (Ritz and Young, 2004), soil amendment strategies adopted in damaged ecosystems, such as liming, require extreme diligence to ensure that all fungal nutrient, metal, substrate requirements are addressed and achieved.

The objective of the present study is to determine fungi diversity and abundance in selected limed and unlimed areas contaminated with metals in the Northern Ontario Region. Soil respiration, fungi cultures and Phospholipid Fatty Acid (PLFA) were analyzed.

\section{Materials and Methods}

\section{Soil Sampling and Processing}

Soil sampling was completed as described in Goupil and Nkongolo (2014) at seven sites that include Wahnapitae Hydro-Dam, Daisy Lake, Kingsway, Kelly Lake, St.Charles (Hagar), Onaping Falls and Capreol (Fig. 1). Each sample was dried at room temperature $\left(25^{\circ} \mathrm{C}\right)$ for $48 \mathrm{~h}$. It was then sifted with a $2 \mathrm{~mm}$ sieve to remove all forms of debris. Three soil samples from each of the limed, unlimed or reference sites were mixed to produce a 'master' limed, unlimed or reference soil sample to be used later for fungal analysis. These "master mix" samples were used for serial dilutions. Only the top $5 \mathrm{~cm}$ (LFH layer) of organic soil was analyzed because it was hypothesized that the majority of fungi colonies would be present within this soil horizon.

\section{Fungal Isolation Method}

All materials, except the soil samples, were autoclaved before use. Serial dilutions were subsequently prepared. For that purpose, $10.0 \mathrm{~g}$ of soil was mixed with $90.0 \mathrm{~mL}$ of sterile $\mathrm{H}_{2} \mathrm{O}$ resulting in a dilution of $1 / 10$. A sterile stopper was then firmly placed on the Erlenmeyer flask containing the 1/10 dilution. The solution was shaken vigorously for $1 \mathrm{~h}$. Four successive dilutions by a factor of 10 were then prepared. They include 1/100, 1/1000, 1/10000, $1 / 100000$ and $1 / 1000000$.

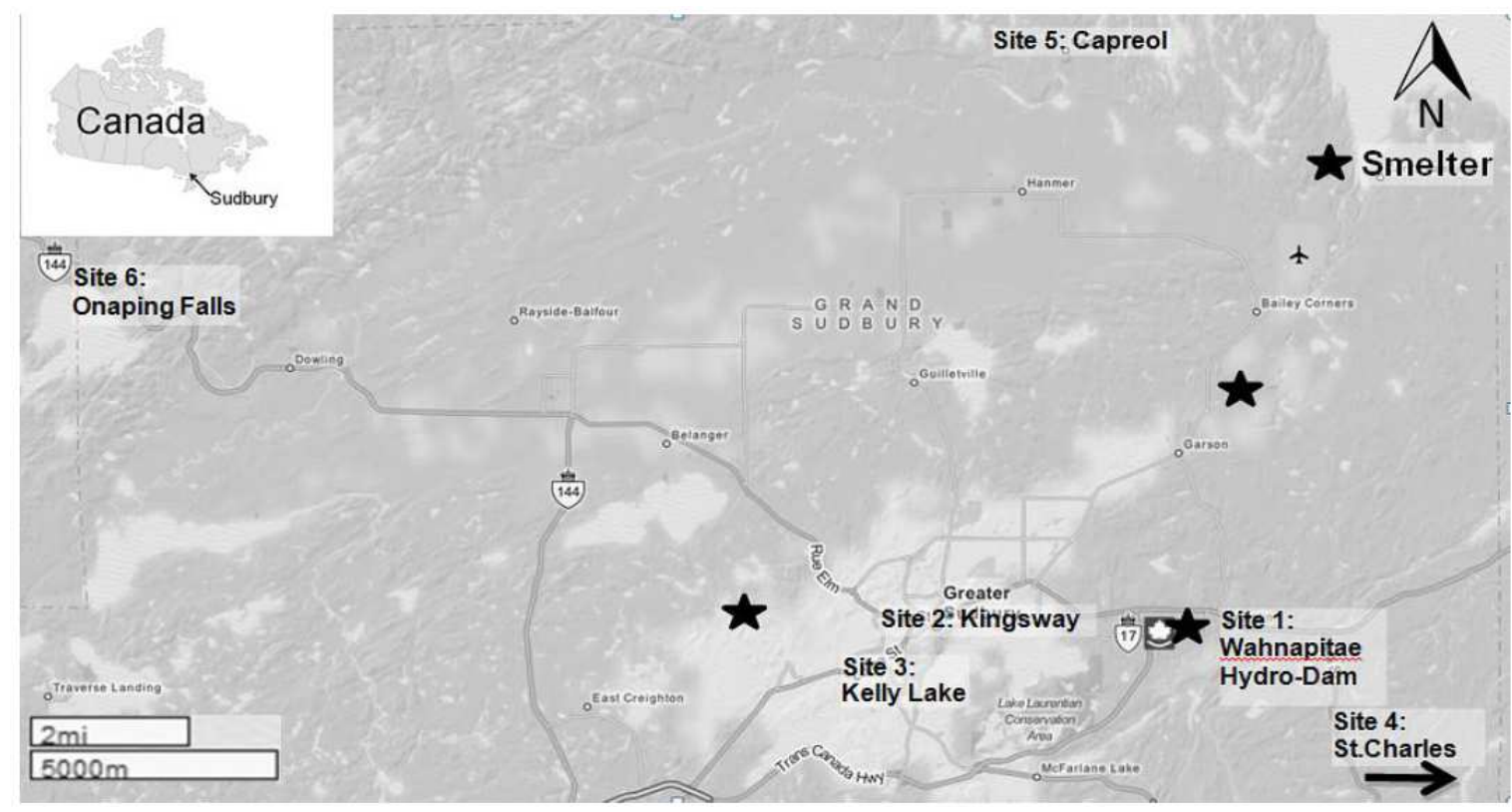

Fig. 1. Locations of sampling areas from the Greater Sudbury Region. Site 1: Wahnapitae Hydro-Dam; Site 2: Kingsway; Site 3: Kelly Lake; Site 4: St.Charles (Hagar); Site 5: Capreol and Site 6: Onaping Falls. Sites 4, 5 and 6 were used as reference sites. St.Charles (Hagar) is outside the map as a reference site and is about 50-60 km from Sudbury. Source: Edited from Google Map 2014 
Two medium types were used for this study, namely Sabouraud Dextrose Agar (SDA) and Malt Extract Agar (MEA). SDA is a multipurpose growing medium for numerous fungal species whereas, MEA is an ideal medium for the cultivation of yeasts and molds. For each medium (SDA and MEA), six plates including a control and different diluted solutions were prepared and duplicated. The labelled plates were inoculated with 0.1 $\mathrm{mL}$ of each solution respectively. The inocula were evenly spread over the surface of the agar plate using a sterile glass rod. The plates were then incubated at $26^{\circ} \mathrm{C}$ until colony masses were easily observed. The plates were examined every day starting at 3-4 days after incubation.

\section{Slide Preparation}

All standard microscope slides were cleaned with $95 \%$ ethanol. A few drops of lactophenol cotton blue were then placed on the slides. With the aid of a pin probe, parts of a fungal colony were placed onto the slide. A cover slip was then placed onto the mount. Slides were properly labeled and air dried before storage. Fungi identification was performed using classification guides and was based on microscopic morphology and colony appearance on the media. The reference guides included detection and isolation of soil fungi (Davet and Rouxel, 2000); Compendium of soil fungi (Domsch et al., 2007); Identification of fungi: An illustrated introduction with keys, glossary and guide to literature (Dugan, 2006); A laboratory guide to common Penicillium species (Pitt and Hocking, 1985); Pictorial atlas of soil and seed fungi: Morphologies of cultured fungi and key to species (Watanabe, 2002); and the Mucorales (Zycha and Siepmann, 1970).

\section{Phospholipid Fatty Acid (PLFA) Analysis and Soil Respiration}

Phospholipid Analysis (PLFA) was performed at FAME Lab, Microbial ID. Inc, Newark, Delaware (USA) as described in Buyer and Saaser (2012). Soil respiration was assessed using the Solvita Soil Test as described in Goupil and Nkongolo (2014). Soil samples were dried in an incubator at $45^{\circ} \mathrm{C}$ for $24 \mathrm{~h}$ prior to the test. Dried soil samples were weighed into a capillary cup after placing a fiber filter in the bottom of the cup. Each beaker, containing $40 \mathrm{~g}$ of dried soil, was placed into a glass jar with the use of forceps. Following this, $20 \mathrm{~mL}$ of distilled water was placed into the glass jar. A $\mathrm{CO}_{2}$ probe was then inserted into the glass jar using forceps. Jars were opened $24 \mathrm{~h}$ later to remove the probes. Probe color was determined using a Digital Color Reader (DCR) as per the manufacturer instructions. Interpretations of the DCR provided data were based on Solvita's overall guidelines.

\section{Statistical Analysis}

Fungal diversity and abundance in unlimed and limed soil samples were compared using Student t-tests. One-Way Analysis of Variance (ANOVA) tests were also conducted between limed, unlimed and reference soil samples for fungal diversity and abundance. Individual differences were determined using Tukey's multiple range test.

\section{Results}

\section{Soil pH Analysis}

The $\mathrm{pH}$ in unlimed sites was consistent with that documented for soils on coarser textured soils with coniferous vegetation on the Canadian Shield of at $<4$, classified as extreme acid $(15,16)$. The $\mathrm{pH}$ in limed sites was significantly higher ranging from 4.12 to 6.75 in the top organic layer compared to unlimed sites (Table 1). The liming did maintain an increase in soil $\mathrm{pH}$ from extremely acid to slightly acid, even 20 to 35 years after liming applications.

\section{Fungi Diversity and Abundance}

Figure 2 shows the long term effect of liming on plant vegetation and population complexity. All fungal species identified in limed and unlimed sites as well as in the reference sites are described in Fig. 3-5. Venn diagrams (Fig. 3-5) also show different fungi species and their shared or specific site location. Mean number of fungi and mean level of fungi abundance for limed, unlimed and reference sites are presented in Table 2 and 3. The most abundant fungi species are described in Table 4.

Table 1. Mean $\mathrm{pH}$ for limed, unlimed and reference sites in Northern Ontario

\begin{tabular}{lll}
\hline Site & $\mathrm{pH} \mathrm{H} \mathrm{H}_{2} \mathrm{O}$ & $\mathrm{pH} \mathrm{CaCl}$ \\
\hline Kelly Lake limed & 6.41 & 6.13 \\
Kelly Lake unlimed & 3.75 & 3.37 \\
Kingsway limed & 4.67 & 4.35 \\
Kingsway unlimed & 3.87 & 2.35 \\
Wahnapitae Hydro-Dam limed & 6.75 & 6.34 \\
Wahnapitae Hydro-Dam unlimed & 3.82 & 3.56 \\
Capreol (reference site) & 3.92 & 3.43 \\
St.Charles (Hagar) (reference site) & 3.50 & 3.23 \\
Onaping Falls (reference site) & 4.84 & 3.92 \\
\hline
\end{tabular}

Table 2. Number of different fungi species within medium for limed, unlimed and reference sites

\begin{tabular}{llc}
\hline & Number of species (Mean \pm SE)* \\
Treatment & SDA & MEA \\
\hline Limed sites & $7.25 \mathrm{a}$ & $5.13 \mathrm{a}$ \\
& \pm 0.53 & \pm 0.95 \\
Unlimed sites & $5.13 \mathrm{~b}$ & $5.63 \mathrm{a}$ \\
& \pm 0.44 & \pm 0.42 \\
Reference sites & $5.83 \mathrm{ab}$ & $7.50 \mathrm{a}$ \\
& \pm 0.31 & \pm 0.85 \\
\hline
\end{tabular}

Limed and unlimed sites include: Wahnapitae Hydro-Dam, Daisy Lake, Kingsway and Kelly Lake. Reference sites include: St.Charles (Hagar), Onaping Falls and Capreol

* Means in columns with a common letter are not significantly different based on Tukey multiple comparison test $(p \geq 0.05)$. $\mathrm{SE}=$ Standard error 


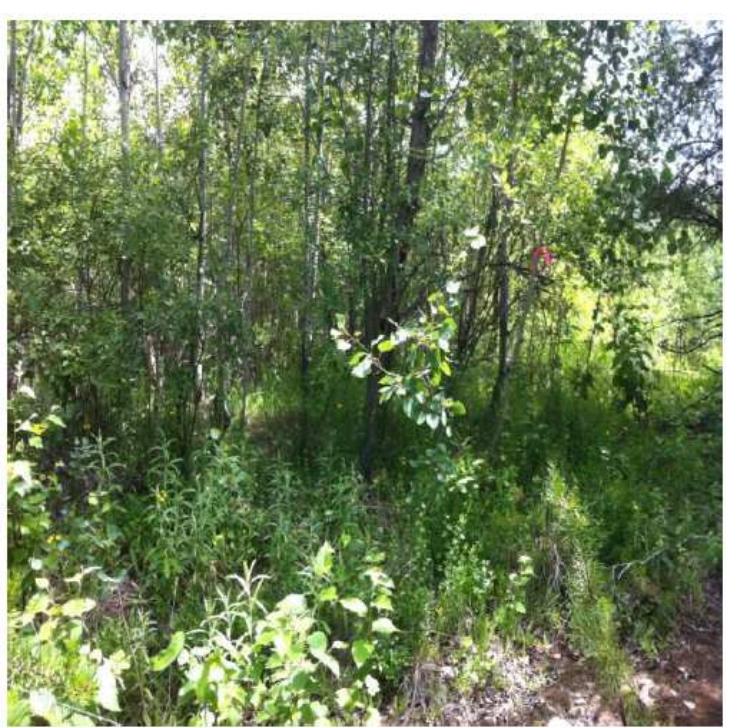

(a)

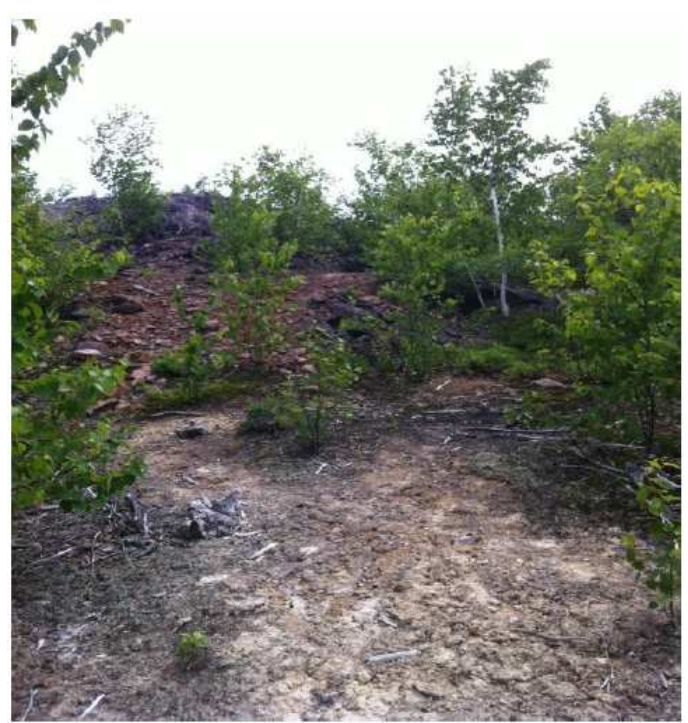

(b)

Fig. 2. Wahnapitae Hydro-Dam site (a) Limed area and (b) Unlimed area

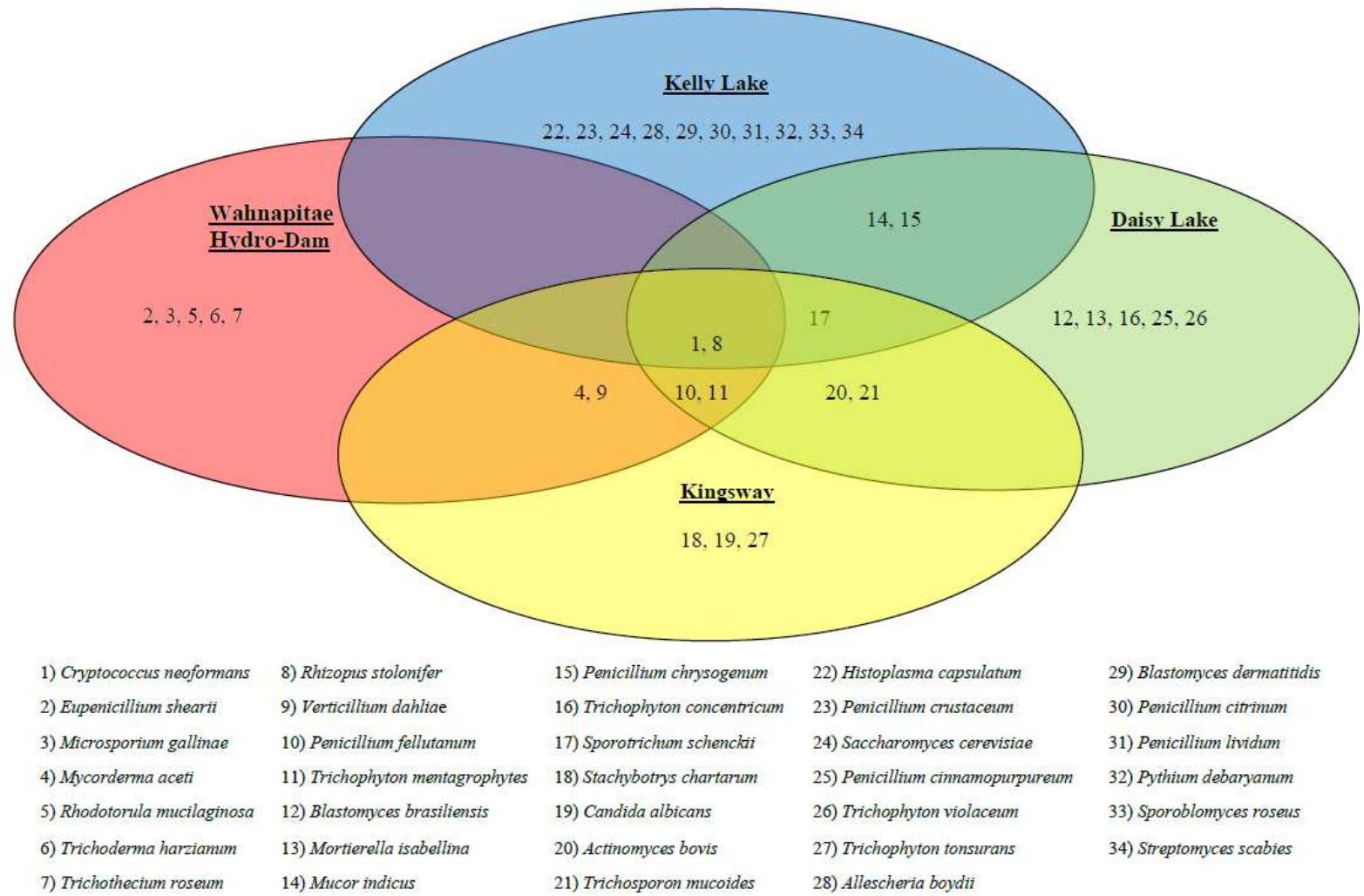

Fig. 3. Venn diagram illustrating common fungi species among limed areas based on SDA and MEA medium analysis

A total of 52 fungi species belonging to 34 genera were identified. Some species were specific to one or two sites, while others were present in the majority of the sites including the reference sites. A total of 23 fungi species were identified in samples from limed areas based on fungi growth on SDA medium plates, while 17 species were observed in samples from unlimed sites. A total of 18 fungi species were found in the reference sites. These results indicate that fungal diversity is higher in limed soils compared to unlimed soils based on SDA medium growth (Table 2). 


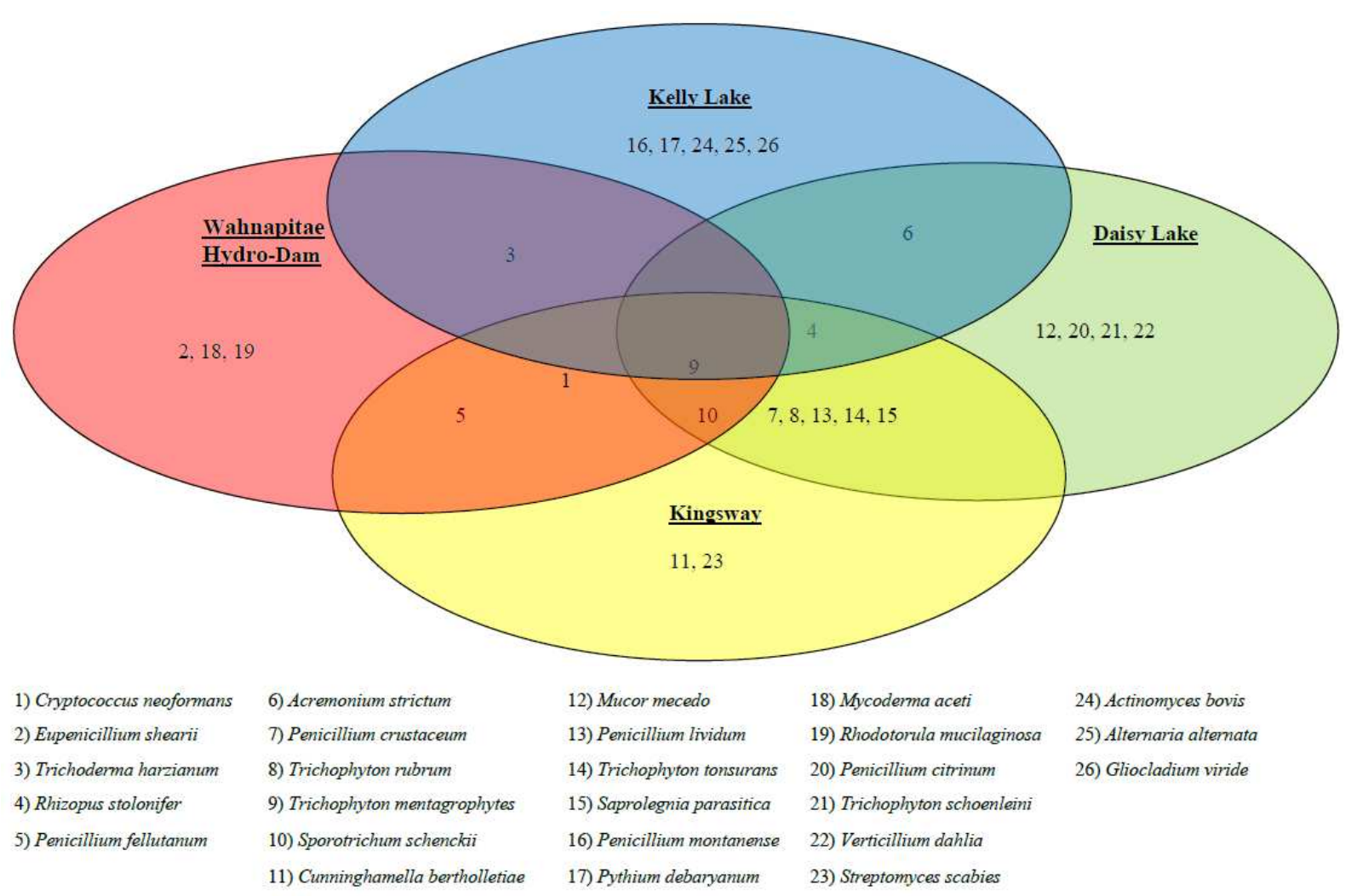

Fig. 4. Venn diagram illustrating common fungi species among unlimed areas based on SDA and MEA medium analysis

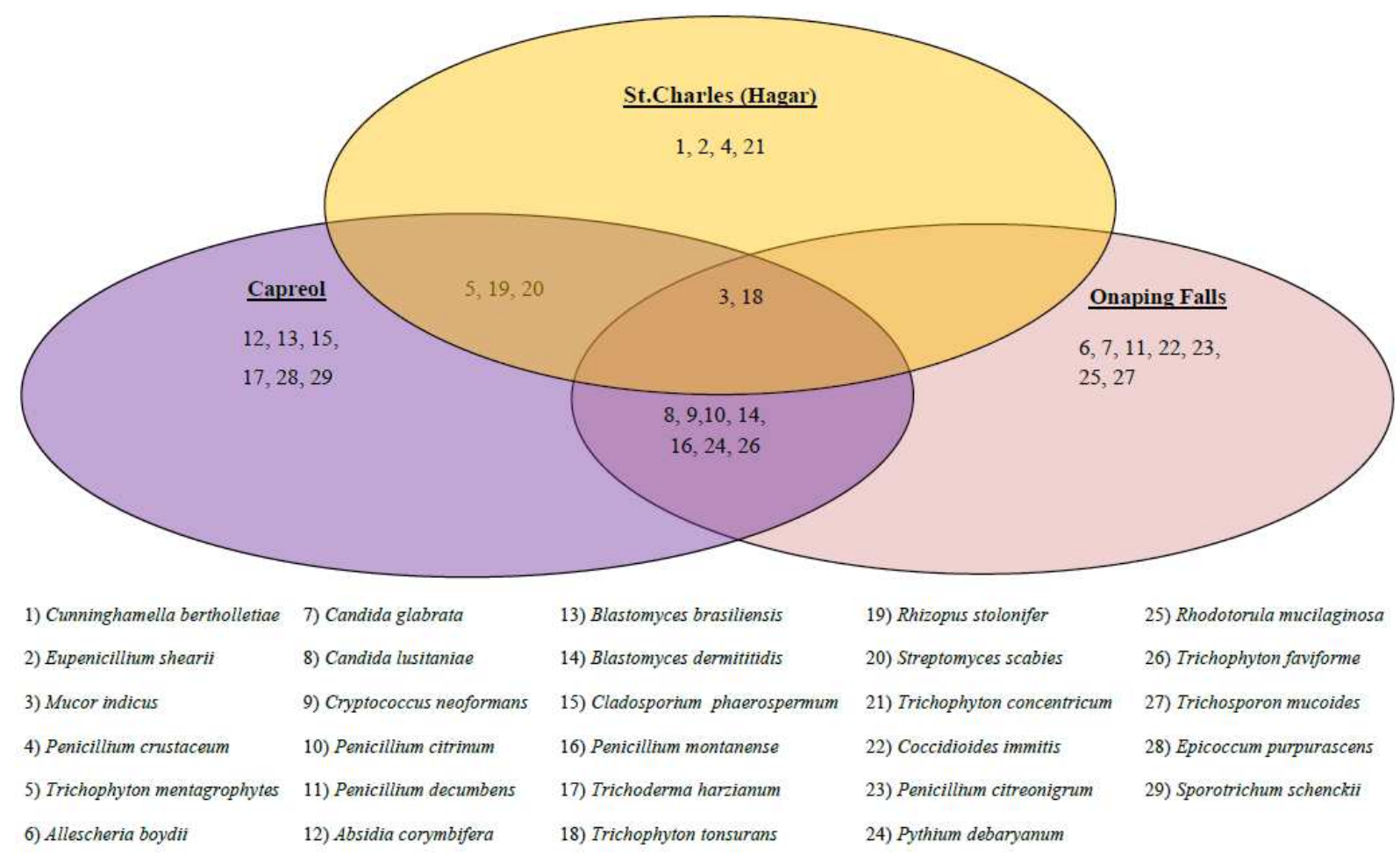

Fig. 5. Venn diagram illustrating common fungi species among reference sites based on SDA and MEA medium analysis 
No significant difference was observed for fungi diversity based on MEA medium growth. Overall, fungi growth on the MEA medium revealed the presence of 21 species in samples from limed areas and 19 species from unlimed areas. A total of 20 species were found in the three reference sites based on MEA growth analysis.

\section{Fungi Abundance Based on Medium}

Optimal fungal growth was observed on SDA medium at dilution factors of $10-1$ to $10-4$ and at $10-1$ to $10-3$ dilution factors for the MEA medium. In both media, the majority of the fungal growth was observed within the first 7 to 10 days post inoculation. Table 4 described for each site the species that was the most abundant based on SDA and MEA growth. The most prevalent fungi species on the SDA medium include Cryptococcus neoformans, Acremonium strictum, Candida albicans, Cunninghamella bertholletiae, Penicillium fellutanum, Sporotrichum schenckii, Trichophyton mentagrophytes and Penicillium citrinum. For the MEA medium, Cryptococcus neoformans, Streptomyces scabies, Sprorotrichum schenckii, Acremonium strictum, Mycoderma aceti, Penicillium montanense, Trchosporon mucoides, Sporotrichum schenckii and Trichophyton tonsurans were the most prevalent species. In general, 41 species were identified on SDA medium and 36 species on MEA medium.

\section{Fungi Species Distribution in Limed and Unlimed Areas}

\section{Distribution Among Sites}

Fungi species distribution was based on growth on SDA and MEA media. For limed sites, $70 \%$ of the fungi species belong to the Ascomycota phylum, 12\% Basidiomycota, 9\% Zygomycota, 6\% Deuteromycota and 3\% Oomycota. At the species level, Cryptococcus neoformans and Rhizopus stolonifer were found in all the areas. Five fungi species were specific to Wahnapitae Hydro-Dam, three different species specific to Kingsway, five to Daisy Lake and ten to Kelly Lake sites (Fig. 3).

For unlimed sites, $65 \%$ of the fungi species belong to the Ascomycota phylum, 8\% Basidiomycota, 11\% Zygomycota, 8\% Deuteromycota and 8\% Oomycota. Trichophyton mentagrophytes was a common species to all the areas, while three species were specific to Wahnapitae Hydro-Dam, two to Kingsway, four to Daisy Lake and five to Kelly Lake sites. Other species were present in some sites and absent in others (Fig. 4).

Table 3. Mean fungi abundance in soil samples from limed, unlimed and reference sites based on growth on SDA and MEA media

\begin{tabular}{lll}
\hline & Abundance (Mean c.f.u./g. \pm SE) \\
& SDA & MEA \\
\hline Treatment & $1.82 \times 10^{8} \mathrm{a}$ & $1.54 \times 10^{8} \mathrm{a}$ \\
Limed sites & $\pm 5.17 \times 10^{7}$ & $\pm 7.84 \times 10^{7}$ \\
& $8.11 \times 10^{7} \mathrm{~b}$ & $1.61 \times 10^{8} \mathrm{a}$ \\
Unlimed sites & $\pm 1.73 \times 10^{7}$ & $\pm 4.44 \times 10^{7}$ \\
Reference sites & $4.0 \times 10^{8} \mathrm{a}$ & $1.36 \times 10^{9} \mathrm{~b}$ \\
& $\pm 1.22 \times 10^{8}$ & $\pm 8.43 \times 10^{8}$
\end{tabular}

Limed and unlimed sites include: Wahnapitae Hydro-Dam, Daisy Lake, Kingsway and Kelly Lake. Reference sites include: St.Charles (Hagar), Onaping Falls and Capreol * Means in columns with a common letter are not significantly different based on Tukey multiple comparison test $(p \geq 0.05)$. $\mathrm{SE}=$ Standard Error

Table 4. Fungi abundance

\begin{tabular}{lll} 
Table 4. Fungi abundance & Most abundant species & Abundance (C.F.U./g) \\
\hline Site & & $3.38 \times 10^{6}$ \\
SDA medium & Sporotrichum schenckii & $5.26 \times 10^{7}$ \\
Daisy Lake Limed & Acremonium strictum & $1.12 \times 10^{8}$ \\
Daisy Lake Unlimed & Candida albicans & $3.42 \times 10^{7}$ \\
Kingsway Limed & Cunninghamella bertholletiae & $2.66 \times 10^{8}$ \\
Kingsway Unlimed & Cryptococcus neoformans & $1.06 \times 10^{8}$ \\
Kelly Lake Limed & Cryptococcus neoformans & $7.77 \times 10^{7}$ \\
Kelly Lake Unlimed & Penicillium fellutanum & $1.22 \times 10^{7}$ \\
Wahnapitae Hydro-Dam Limed & Trichophyton mentagrophytes & $1.01 \times 10^{8}$ \\
Wahnapitae Hydro-Dam Unlimed & & $2.79 \times 10^{8}$ \\
Reference sites & Trichophyton mentagrophytes & $1.05 \times 10^{8}$ \\
St.Charles (Hagar) & Penicillium citrinum & $6.18 \times 10^{6}$ \\
Onaping Falls & Trichophyton mentagrophytes & $1.37 \times 10^{8}$ \\
Capreol & & $6.60 \times 10^{7}$ \\
MEA medium & Sporotrichum schenckii & $1.66 \times 10^{8}$ \\
Daisy Lake Limed & Acremonium strictum & $4.89 \times 10^{8}$ \\
Daisy Lake Unlimed & Mycoderma aceti & $3.86 \times 10^{8}$ \\
Kingsway Limed & Cryptococcus neoformans & \\
Kingsway Unlimed & Streptomyces scabies & $1.59 \times 10^{8}$ \\
Kelly Lake Limed & Penicillium montanense & $1.23 \times 10^{8}$ \\
Kelly Lake Unlimed & & $1.61 \times 10^{8}$ \\
Reference sites & Trichophyton tonsurans & \\
St.Charles (Hagar) & Trichosporon mucoides &
\end{tabular}


For reference sites, $69 \%$ of the fungi species belong to the Ascomycota phylum, 10\% Basidiomycota, 14\% Zygomycota, 3\% Deuteromycota and 4\% Oomycota. At the species level, Mucor indicus and Trichophyton tonsurans were common to all the sites. Six species where specific to Capreol reference site, seven to Onaping Falls and four to St.Charles (Hagar) (Fig. 5).

\section{Distribution within Sites}

\section{SDA Medium}

For Wahnapitae Hydro-Dam site, Penicillium fellutanum, Rhodotorula mucilaginosa, Trichoderma harzianum and Trichophyton mentagrophytes were the most commonly found in limed areas while Eupenicillium shearii, Penicillium fellutanum, Sporotrichum schenckii and Trichophyton mentgrophytes were the most frequent in unlimed sites.

For Daisy Lake, Mortierella isabellina, Penicillium chrysogenum and Sporotrichum schenckii were most common species in limed site while Acremonium strictum, Penicillium lividum and Rhizopus stolonifer were the most prevalent in unlimed sites.

For Kingsway, Candida albicans, Penicillium fellutanum, Rhizopus stolonifer and Trichophyton mentagrophytes were the most frequent while Cunninghamella bertholletiae and Saprolegnia parasitica were the most common in unlimed sites.

For Kelly Lake, Cryptococcus neoformans, Penicillium crustaceum and Sporotrichum schenckii were the most abundant while Cryptococcus neoformans and Rhizopus stolonifer were the most frequent in unlimed sites.

For the reference site, Cunninghamella bertholletiae, Eupenicillium shearii, Mucor indicus, Penicillium crustaceum and Trichophyton mentagrophytes were the most common in St.Charles (Hagar); Allescheria boydii, Candida glabrata, Candida lusitaniae, Cryptococcus neoformans, Mucor indicus, Penicillium citrinum and Penicillium decumbens in Onaping Falls; Absidia corymbifera, Blastomyces brasiliensis, Blastomyces dermatitidis, Cladosporium sphaerospermum, Mucor indicus, Penicillium montanense, Trichoderma harzianum, Trichophyton mentagrophytes and Trichophyton tonsurans in Capreol.

\section{MEA Medium}

For Wahanapitae Hydro-Dam, Mycoderma aceti and Trichophyton mentagrophytes were more common in limed area while Cryptococcus neoformans, Mycoderma aceti and Trichophyton mentagrophytes were most frequent in unlimed site.

For Daisy Lake, Penicillium chrysogenum, Sporotrichum schenckii and Trichophyton mentagrophytes were the most abundant in limed area while Acremonium strictum, Saprolegnia parasitica and Verticillium dahlia were the most frequent in unlimed site.

For Kingsway, Mycoderma aceti and Trichophyton mentagrophytes were the most common while Cryptococcus neoformans, Saprolegnia parasitica, Sporotrichum schenckii and Trichophyton mentagrophytes were most frequent in unlimed site.

For Kelly Lake, Penicillium lividum and Streptomyces scabies were the most abundant in limed area while Acremonium strictum, Actinomyces bovis and Alternaria alternata were the most prevalent in unlimed site.

For reference sites, Penicillium crustaceum, Rhizopus stolonifer, Streptomyces scabies, Trichophyton concentricum, Trichophyton mentagrophytes and Trichophyton tonsurans were the most common in St.Charles (Hagar); Blastomyces dematitidis, Coccidioides immitis, Mucor indicus, Penicillium citreonigrum, Penicillium citrinum, Penicillium montanense, Pythium debaryanum, Rhodotorula mucilaginosa, Trichophyton faviforme, Trichophyton tonsurans and Trichosporon mucoides in Onaping Falls; and Blastomyces dermatitidis, Candida lusitaniae, Cryptococcus neoformans, Epicoccum purpurascens, Penicillium citrinum, Pythium debaryanum, Rhizopus stolonifer, Sporotrichum schenckii, Streptomyces scabies and Trichophyton faviforme in Capreol.

\section{PLFA Analysis}

Results of phospholipid Fatty acid analysis are described in Table 5. This analysis revealed higher microbial biomass in samples from limed areas compared to unlimed samples. Significant differences were also observed between limed and unlimed site for total fungi and arbuscular mycorrhizal fungi abundance based on the PLFA analysis. In general there more bacteria than fungi in all the sites analyzed (Table 5). In fact total bacteria represent 68.4, 74.3 and $71.4 \%$ for unlimed, limed and references sites, respectively. These values were only $9.8 \%$ (for unlimed), 6.7\% (for limed) and 9.4\% (for reference sites) for total fungi biomass. The ratio between fungi and bacteria was very low for all the groups. A sensitive difference between fungi/bacteria ratio for limed and unlimed sites was observed (Table 6). There were twice more Gram (-) bacteria than Gram $(+)$ in all the sites (Table 5).

\section{Soil Respiration}

There was significant higher soil respiration rates in limed sites compared to unlimed areas. Respiration rates for the reference sites were similar to those documented for the limed sites (Table 5). 
Table 5. Total microbial biomass, fungi and AM fungi biomass and soil respiration in limed and unlimed sites in Northern Ontario using phospholipid fatty acid analysis and Solvita test*

\begin{tabular}{|c|c|c|c|c|c|c|c|c|}
\hline \multirow[b]{3}{*}{ Site } & \multirow{3}{*}{$\begin{array}{l}\text { Total } \\
\text { microbial } \\
\text { biomass }\end{array}$} & \multirow{3}{*}{$\begin{array}{l}\text { AM } \\
\text { Fungi } \\
\text { (ng/g) }\end{array}$} & \multirow{3}{*}{$\begin{array}{l}\text { Fungi } \\
\text { (ng/g) }\end{array}$} & \multirow{3}{*}{$\begin{array}{l}\text { Fungi } \\
\text { /bacteria } \\
\text { ratio }\end{array}$} & \multirow{3}{*}{$\begin{array}{l}\text { Gram (-) } \\
\text { bacteria } \\
(\mathrm{ng} / \mathrm{g})\end{array}$} & \multirow{3}{*}{$\begin{array}{l}\text { Gram }(+) \\
\text { bacteria } \\
(\mathrm{ng} / \mathrm{g})\end{array}$} & \multicolumn{2}{|c|}{$\mathrm{CO}_{2}-\mathrm{C}(\mathrm{mg} / \mathrm{kg}(\mathrm{ppm}))$} \\
\hline & & & & & & & ---------- & - n--- \\
\hline & & & & & & & Summer & Fall \\
\hline Unlin & $145.72 \mathrm{a} \pm 33.73$ & $6.1 \mathrm{a} \pm 1.00$ & $11.8 \mathrm{a} \pm 7.0$ & 0.18 & $67.1 \mathrm{a} \pm 6.49$ & $37.3 \mathrm{a} \pm 3.42$ & $57.0 \mathrm{a}$ & $52.3 a$ \\
\hline Limed sites & $339.63 b \pm 83.25$ & $14.9 \mathrm{~b} \pm 1.8$ & $26.7 \mathrm{~b} \pm 4.07$ & 0.14 & $174.6 \mathrm{~b} \pm 1.9$ & $76.1 b \pm 3.94$ & $69.3 b$ & $71.0 \mathrm{~b}$ \\
\hline Reference sites & $431.81 b \pm 80.36$ & $19.4 b \pm 1.6$ & $42.5 b \pm 4.37$ & 0.16 & $212.8 \mathrm{~b} \pm 5.66$ & $95.3 \mathrm{~b} \pm 0.52$ & $74.5 \mathrm{~b}$ & $69.0 \mathrm{~b}$ \\
\hline
\end{tabular}

Unlimed and limed sites: Wahnapitae Hydro-Dam, Kingsway and Kelly Lake; Reference sites: Onaping Falls, Capreol and St.Charles (Hagar).

*Means in columns with a common letter are not significantly different based on Tukey multiple comparison test ( $\mathrm{p} \geq 0.05$ )

Table 6. Phospholipid Fatty Acid (PLFA) ratios analyzed in soil samples from the Greater Sudbury Region

\begin{tabular}{|c|c|c|c|c|c|c|c|}
\hline Sites & $\begin{array}{l}\text { Fungi/ } \\
\text { Bacteria }\end{array}$ & $\begin{array}{l}\text { Predator/ } \\
\text { Prey }\end{array}$ & $\begin{array}{l}\text { Gram positive/ } \\
\text { Gram negative }\end{array}$ & $\begin{array}{l}\text { Saturated/ } \\
\text { Unsaturated }\end{array}$ & $\begin{array}{l}\text { Mono/ } \\
\text { Poly }\end{array}$ & $\begin{array}{l}16 \mathrm{w} / 16 \\
\text { cyclo }\end{array}$ & $\begin{array}{l}18 w / 19 \\
\text { cyclo }\end{array}$ \\
\hline Unlimed sites & 0.18 & 0.04 & 0.74 & 1.17 & 3.82 & 2.43 & 0.80 \\
\hline Limed sites & 0.14 & 0.02 & 0.55 & 0.77 & 6.44 & 2.64 & 2.30 \\
\hline Reference sites & 0.16 & 0.05 & 0.48 & 0.74 & 4.00 & 3.00 & 1.12 \\
\hline
\end{tabular}

\section{Discussion}

\section{Soil Metal Content}

Detail of soil metal analysis has been described in (Nkongolo et al., 2013; Goupil and Nkongolo, 2014; Tran et al., 2014). Hence no metal analysis was conducted in the present study. These previous reports show no significant differences between limed and unlimed areas with regards to total element concentrations with the exception of arsenic. As expected, the limed samples contained higher levels of calcium and magnesium compared to unlimed sites. Based on these studies, there were significantly higher contents of bioavailable aluminum, iron, manganese and strontium in unlimed sites compared to limed area. The levels of bioavailable cobalt, copper, total metals that was bioavailable was very small (Nkongolo et al., 2013; Goupil and Nkongolo, 2014; Tran et al., 2014).

\section{Soil Characteristics, Fungi Abundance and Diversity}

Fungi diversity and abundance in a region are generally tribute to soil chemical and physical conditions. Smith and Doran (1996) reported that fungi prefer acidic soil since their growth was generally observed in the soil with a $\mathrm{pH}$ between 2 and 7 with an optimum of 5 . However, some fungi have a better growth rate in alkaline soils compared to acidic soils (Kendrick, 2000). In fact, soil pH affects many biological processes. For example, organic matter mineralization is slowed down or stopped at highly acidic or alkaline $\mathrm{pH}$ levels, which is attributed to poor microbial activity linked to bacteria (Smith and Doran, 1996). At low pH levels, nitrification and nitrogen fixation will also be inhibited (Smith and Doran, 1996). Furthermore, the solubility of heavy metals as well as the mobility and degradation of herbicides and insecticides are $\mathrm{pH}$ dependant (Smith and Doran, 1996). Soil $\mathrm{pH}$ affects cation availability which in turn influences aggregate stability because multivalent cations, like calcium ions, act as bridges between organic colloids and clays (Smith and Doran, 1996).

The effects of soil liming include an intricate change in the total nutrient availability in the soil as well as an increase in soil pH (Mengel and Kirkby, 1987). Some nutrients prove more useful for some species of fungi than others and the levels of such macro and micro nutrients in the substrate dictate the survival of fungi species (Kendrick, 2000). Fungi use a variety of metals to accomplish their vital processes. In the present study, the total and bioavailable concentration of nutrients and metal elements in the limed and unlimed organic surface horizons (LFH) of soils were determined to better understand their role on fungi sustainability. Elemental analysis revealed significantly lower concentrations of total arsenic and bioavailable aluminium, iron and strontium in limed sites compared to unlimed sites. As expected, high levels of bioavailable calcium and magnesium were found in limed sites reflecting the addition of the dolomitic and calcitic limestone that was applied 30-40 years ago.

Fungi have the ability to use many metals or elements as food sources while other organisms prove to be intolerant to many elements in their soil environment even at low concentrations. It was difficult to estimate if the low level of bioavailable metals could have any effect in fungi diversity and abundance.

While sharing the common characteristics of Canadian Shield soils, some sites are better suited for some phyla of fungi to grow and thrive based on their respective soil properties. This is why some fungi species are unique to some sites while others are found in all four targeted limed or unlimed sites. For example, for the limed soil, Cryptococcus neoformans and Rhizopus stolonifer were common to all the four targeted sites, namely Wahnapitae Hydro-Dam, Daisy Lake, Kingsway and Kelly Lake, while many other fungi species were site(s)-specific. 
Climatic factors also influence fungi diversity as well as abundance within a region in general. Physical parameters such as temperature, light and even gravity have been found to have significant effects on different fungi species (Kendrick, 2000). Some psychrophilic fungi have been documented to grow at temperatures below $0^{\circ} \mathrm{C}$ while, some thermophilic fungi have the ability to grow and thrive at temperatures above $50^{\circ} \mathrm{C}$ (Kendrick, 2000). Some fungi species require light for fruiting while others are indifferent to illumination (Kendrick, 2000). Several macrofungi are extremely sensitive to gravity while numerous microfungi are totally oblivious to gravity (Kendrick, 2000). Consequently, because the sites of Wahnapitae HydroDam, Daisy Lake, Kingsway, Kelly Lake, St.Charles (Hagar), Onaping Falls and Capreol are geographically separated and distant, they each have different topographic settings resulting in different temperatures and illumination rates (at times) which could have some effects on their respective fungi populations.

\section{Fungi Growth in Culture Media}

In nature, fungi can develop mechanisms to feed themselves from different substrates but when grown on media, nutrients must be added to ensure that fungal colonies will grow (Kendrick, 2000). Two fungal media, namely SDA and MEA, were utilized in this study. Both media are chemically different from one another and allow for variations in terms of fungal diversity and abundance. SDA, a multipurpose medium, is among one of the most widely used fungal media as it allows for numerous fungi species to grow. SDA medium contains sources of carbon, nitrogen as well as vitamins just like all fungal media utilized for commercial purposes. Among its' ingredients, SDA medium contains glucose (to be utilized as a carbon source) and neopeptone and polypeptone agar (utilized as a solidifying agent for nitrogen). SDA $\mathrm{pH}$ is around 5.6 which is slightly acidic and appropriate for the growth of a multitude of fungi species that have an optimal growth at a pH of 5 (Smith and Doran, 1996). Commercially available SDA can include antibiotics such as streptomycin, which does not harm fungi. Such formulations are known as "restrictive" or "selective" while SDA formulations that have no inhibitor are known as "permissive".

To document other possible fungi species growing in sites within Northern Ontario Region, MEA medium was also used. This medium is suited for the isolation, cultivation and enumeration of yeasts and molds. MEA medium provides sources of carbon, protein and nutrients that are necessary for the growth of microorganisms. Because MEA medium contains high concentrations of maltose and other saccharides as energy sources, it primarily allows for yeasts and molds to grow and to some extent some other fungi species.
But bacterial growth is restricted on petri dishes. MEA medium uses dextrin and glycerin as carbon sources and Peptone is utilized as a nitrogen source. Bacteriological agar is the solidifying agent for this particular strand of medium. MEA medium has a $\mathrm{pH}$ of 4.7 .

\section{Fungi Diversity and Abundance}

A significantly high level of fungal diversity was found in limed soil samples compared to unlimed soil samples based on data from SDA growth essays. These data are consistent with (Smith and Doran, 1996) findings. An opposite trend was observed for the MEA medium where more fungal diversity was recorded in the unlimed soil samples compared to the limed ones. These results can be ascribed to chemical and $\mathrm{pH}$ differences between SDA and MEA media.

Variability in fungal abundance follows the same trend as the species diversity. A significantly higher level of fungal abundance was observed in the limed areas compared to the unlimed sites based on SDA medium data. These results support WeymanKaczmarkowa and Pedziwilk's (2000) findings documenting the effects of liming $\left(\mathrm{Ca}(\mathrm{OH})_{2}\right)$ on a number of fungal Colony-Forming Units (CFU). Although a different type of limestone was utilized in their study, they nevertheless recorded elevated mean fungal CFU numbers when soil $\mathrm{pH}$ reached 4.5 (Weyman-Kaczmarkowa and Pedziwilk, 2000) compared to more acidic soils.

For the MEA medium, an opposite trend was observed where more fungal abundance was recorded in the unlimed sites compared to the limed sites. This again can possibly be explained by the chemical ingredients and lower $\mathrm{pH}$ of the MEA medium which is better suited for yeast growth. Higher yeast counts were in fact documented for all sites in the MEA medium.

\section{Soil Respiration and PLFA Analysis}

Soil respiration is known as an ecosystem process by which carbon dioxide is released from the soil by means of root respiration, microbial decomposition of litter and soil organic matter as well as fauna respiration (Yiqi and Zhou, 2006). Soil respiration is intricately linked to the general processes occurring in ecosystems becasuse it is strongly related to ecosystem productivity, soil fertility, as well as regional and global carbon cycles (Yiqi and Zhou, 2006).

While the evaluation of soil respiration to determine soil health is widely adopted, the determination of the individual contributions of the different microorganisms to the total metabolism involved in the soil is rather difficult to undertake in terms of methodology (Pietikåinen et al., 2005). However, according to a model developed by Anderson and Domsch (1974), bacterial and fungal respiration can indeed be calculated using 
inhibitors. In the soil used to develop the method, they obtained a ratio of bacterial to fungal respiration of about 20/80 which supports the hypothesis that the fungal biomass dominates the metabolism of many agricultural and forest soils as previously mentioned (Anderson and Domsch, 1974). Biomass measurements by (Satchell, 1971; Shields et al., 1973; Parkinson, 1973) and as cited by Clark and Paul (1970) also support Anderson and Domsch's (1974) findings. They indicated that soil biological biomass was dominated by the fungal component. Consequently, one could state that fungi are the major decomposers in these soils and as such, their diversity and abundance are crucial to their metabolic activity and ultimately, to soil respiration outputs for a specific region.

It should be pointed out that culture media analysis revealed the diversity and the abundance of fungi species that can grow on the two media used while PLFA tests estimate the amount of living fungi and other microorganisms. Many fungal species elude culturing in the laboratory (van Elsas et al., 2000). To overcome problems associated with non-culturable fungi or bacteria, various methods have been developed to identify and study these organisms including fatty acid analysis and numerous DNA and RNA based methods (Kirk et al., 2004). Fatty acids are the key component of cellular membrane of all living cells. Thus, PLFA provides an accurate census of the current living community. It is a culture-independent tool for investigating microbial populations in ecological studies (Hackl et al., 2005; Kaur et al., 2005).

But the results of the PFLA analysis in the present study show that bacteria are the main components of all the sites surveyed. no significant differences between limed and unlimed sites in total and arbuscular mycorrhizal fungi biomass. Significant differences between the two groups of sites (limed Vs unlimed) were rather observed for total microbial biomass, total fungi and arbuscular mycorrhizal. This clearly indicated that liming has significant long term effect on live microbial communities. The fungi/bacteria ratios were very low indicating a community of fungi/bacteria close to 1 indicates a balance and a system that is adapted to environmental conditions. Since the main lasting effect of liming is soil acidity, the results suggest that the increase in soil $\mathrm{pH}$ generated by liming could be more beneficial to bacteria than to fungi. Overall, there were twice as much Gram (-) bacteria than Gram (+) confirming that all the sites including the reference areas are still severely stressed. This finding does somewhat corroborate with Anderson and Domsch (1974) results. They reported that soil with a low $\mathrm{pH}$ such as in the present study showed the highest level of bacterial activity compared to neutral $(\mathrm{pH}=7.5)$ soil.

\section{Soil Microbial Abundance, Respiration and Metal Content}

It has been demonstrated that fungi are more tolerant to heavy metals as a group in comparison to bacteria (Doelman, 1985; Hiroki, 1992). Furthermore, different biomass measurements or plate counting techniques have revealed that heavy metals will affect bacteria and fungi in a different manner in the soil (Hiroki, 1992; Khan and Scullion, 2002; Maliszewska et al., 1985; Muller et al., 2001). Consequently, metal speciation should affect soil respiration to some extent. Rajapaksha et al. (2004) reported that soil respiration rate was slightly affected by metal contamination and they found that a clear dose-response effect was encountered at added

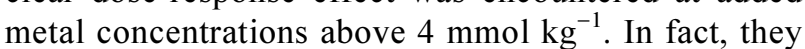
discovered that the highest levels of Copper and Zinc contamination resulted in a $30 \%$ reduction of soil respiration rate compared to the control soil (Rajapaksha et al., 2004). Furthermore, the metal contamination of Zinc and Copper was not differentiated in terms of metal effect on soil respiration (Rajapaksha et al., 2004). Previous reports also indicate that soil respiration rates in the metalcontaminated soils gradually decrease in comparison to the non-contaminated samples throughout the first three days post metal addition, after which soil respiration became stable (Rajapaksha et al., 2004). However, respiration rates following 10 and 60 days of incubation were not significantly different (Rajapaksha et al., 2004). Lastly, following the addition of lime, a short increase in respiration rates in the contaminated soils was apparent (Rajapaksha et al., 2004). Our data showed no apparent effects of metals on microbial communities since in general limed and unlimed areas have similar levels of total and the bioavailable content (Nkongolo et al., 2013). This suggests that the bioavailable elements in the targeted sites might be too small to be harmful to fungi or bacteria.

\section{Conclusion}

The present study reveals that soil liming has significant effect on soil $\mathrm{pH}$ and on diversity of fungi species grown on SDA medium. Such difference was not observed when living fungi were considered. PLFA analysis revealed significant differences between limed and unlimed sites for total microbial biomass and fungi. Overall, soil liming affects both fungi and bacteria, but differences in soil respiration appear to be generated by bacterial activities rather than fungi. Overall, our data suggest that soil $\mathrm{pH}$ might be the most important factor for microbial abundance and activities than metal content. 


\section{Acknowledgement}

We express our appreciation to the Natural Sciences and Engineering Research Council of Canada (NSERC), Vale Limited and Glencore Limited (formerly Xstrata Limited) for their financial support. Thanks to Dr. Nasserulla for assistance with fungi abundance, Dr. Spiers (Elliott Lake Research Lab at Laurentian University) for metal analysis and Ms. Ramya Narendrula for assistance with data analysis and formatting.

\section{Author's Contributions}

Kassandre Goupil: Conducted fungi identification, soil respiration and data analysis and contributed to the manuscript preparation.

Kabwe K. Nkongolo: Coordinated the study, conducted phospholipid fatty acid analyses, integrated all the data and wrote the manuscript.

Sabah Nasserulla: Contributed to fungi identification and data analysis.

\section{Ethics}

The authors declare that there is no conflict of interest.

\section{References}

Anderson, J.P.E. and K.H. Domsch, 1974. Measurement of bacterial and fungal contributions to respiration of selected agricultural and forest soils. Can. J. Microbiol., 21: 314-322. PMID: 1116044

Balsillie, D., W.D. Mcllveen and K. Winterhalder, 1978. Problems of regeneration of stressed ecosystems. Proceedings of the 71st Annual Meeting of the Air Pollution Control Association, (PCA' 78), Houston, TX, pp: 39-39.

Buyer, J. and M. Sasser, 2012. High throughput phospholipid fatty acid analysis of soils. Applied Soil Ecol., 61: 127-130.

DOI: $10.1016 /$ j.apsoil.2012.06.005

Clark, F.E. and E.A. Paul, 1970. The microflora of grassland. Adv. Agron., 22: 375-435. DOI: $10.1016 / \mathrm{S} 0065-2113(08) 60273-4$

Davet, P. and F. Rouxel, 2000. Detection and Isolation of Soil Fungi. 1st Edn., Science Publishers, Enfield, ISBN-10: 1578081254, pp: 188.

Doelman, P., 1985. Resistance of Soil Microbial Communities to Heavy Metals. In: Microbial Communities in Soil, Jensen, V., A. Kjøller and L.H. Sørensen (Edn.), Elsevier Applied Science Publishers, London, pp: 369-384.

Domsch, K.H., W. Gams and T.H. Anderson, 2007. Compendium of Soil Fungi. 2nd Edn., IHW-Verlag, Eching, pp: 672.
Dugan, F.M., 2006. The Identification of Fungi: An Illustrated Introduction with Keys, Glossary and Guide to Literature. 1st Edn., American Phytopathological Society, St. Paul, ISBN-10: 0890543364, pp: 176.

Goupil, K. and K. Nkongolo, 2014. Assessing soil respiration as an indicator of soil microbial activity in reclaimed metal contaminated lands. Am. J. Environ. Sci., 10: 403-411. DOI: $10.3844 /$ ajessp.2014.403.411

Hackl, E., M. Pfeffer, C. Donat, G. Bachmann and S. Zechmeister-Boltenstern, 2005. Composition of the microbial communities in the mineral soil under different types of natural forest. Soil Biol. Biochem., 37: 661-671. DOI: 10.1016/j.soilbio.2004.08.023

Hiroki, M., 1992. Effects of heavy metal contamination on soil microbial population. Soil Sci. Plant Nutr., 38: 141-147. DOI: $10.1080 / 00380768.1992 .10416961$

Kaur, A., A. Chaudhary, A. Kaur, R. Choudhary and R. Kaushik, 2005. Phospholipid fatty acid: A bioindicator of environment monitoring and assessment in soil ecosystem. Curr. Sci., 89: 1103-1112.

Kendrick, B., 2000. The Fifth Kingdom. 3rd Edn., Focus Pub., Newburyport, ISBN-10: 1585100226, pp: 373.

Khan, M. and J. Scullion, 2002. Effects of metal $(\mathrm{Cd}$, $\mathrm{Cu}, \mathrm{Ni}, \mathrm{Pb}$ or $\mathrm{Zn}$ ) enrichment of sewage-sludge on soil micro-organisms and their activities. Applied Soil Ecol., 20: 145-155. DOI: 10.1016/S0929-1393(02)00018-5

Kirk, J.L., L.A. Beaudette, H. Miranda, P. Moutoglis and J.N. Klironomos et al., 2004. Methods of studying soil microbial diversity. J. Microb. Meth., 58: 169188. PMID: 15234515

Maliszewska, W., S. Dec, H. Wierzbicka and A. Woz'niakowska, 1985. The influence of various heavy metal compounds on the development and activity of soil micro-organisms. Environ. Pollut. Series A, Ecol. Biological., 37: 195-215. DOI: 10.1016/0143-1471(85)90041-8

Mengel, K. and E.A. Kirkby, 1987. Principles of Plant Nutrition. 4th Edn., International Potash Institute, Worblaufen-Bern, ISBN-10: 3906535037, pp: 687.

Muller, A.K., K. Westergaard, S. Christensen and S.J. Sørensen, 2001. The effect of long-term mercury pollution on the soil microbial community. FEMS Microbiol. Ecol., 36: 11-19. DOI: $10.1111 / \mathrm{j} .1574-6941.2001 . t b 00821 . x$

Nielsen, M.N. and A. Winding, 2002. Microorganisms as Indicators of Soil Health. 1st Edn., NERI, Roskilde, ISBN-10: 8777726588, pp: 82.

Nkongolo, K.K., G. Spiers, P. Beckett, R. Narendrula and G. Theriault et al., 2013. Long-term effects of liming on soil chemistry in stable and eroded upland areas in a mining region. Water Air Soil Pollut., 224: 1-14. DOI: 10.1007/s11270-013-1618-x 
Parkinson, D., 1973. Techniques for the Study of Soil Fungi. In: Modern Methods in the Study of Microbial Ecology: Proceedings of a Symposium Held at the Agricultural College, Rosswall, T. (Ed), Swedish Naural Science Research Council, Stockholm, pp: 29-36.

Pietikåinen, J., M. Pettersson and E. Bååth, 2005. Comparison of temperature effects on soil respiration and bacterial and fungal growth rates. FEMS Microbiol. Ecol., 52: 49-58. PMID: 16329892

Pitt, J.I. and A.D. Hocking, 1985. A Laboratory Guide to Common Penicillium Species. 1st Edn., Commonwealth Scientific and Industrial Research Organization, Division of Food Research, pp: 184.

Rajapaksha, R.M.C.P., M.A. Tobor-Kaplon and E. Bååth, 2004. Metal toxicity affects fungal and bacterial activities in soil differently. Applied Environ. Microbiol., 70: 2966-2973.

DOI: 10.1128/AEM.70.5.2966-2973.2004

Ritz, K. and I.M. Young, 2004. Interactions between soil structure and fungi. Mycologist, 18: 52-59. DOI: $10.1017 / \mathrm{S} 0269-915 \mathrm{X}(04) 00201-0$

Satchell, J.E., 1971. Feasibility Study of an Energy Budget for Meathop Wood. In: Productivity of Forest Ecosystems, Ecology and Conservation, Duvigneaud, P. (Ed), UNESCO, Paris, pp: 619-630.

Shields, J.A., E.A. Paul, W.E. Lowe and D. Parkinson, 1973. Turnover of microbial tissue in soil under field conditions. Soil Biol. Biochem., 5: 753-764. DOI: $10.1016 / 0038-0717(73) 90020-5$

Smith, J.L. and J.W. Doran, 1996. Measurement and Use of $\mathrm{pH}$ and Electrical Conductivity for Soil Quality Analysis. In: Methods for Assessing Soil Quality, Doran, J.W. and A.J. Jones (Eds.), Soil Science Society of America, Madison, pp: 169-186.

Theriault, G., K.K. Nkongolo, R. Narendrula and P. Beckett, 2013. Molecular and ecological characterisation of plant populations from limed and metal-contaminated sites in Northern Ontario (Canada): ISSR analysis of white birch (Betula papyrifera) populations. Chem. Ecol., 29: 1-13. DOI: $10.1080 / 02757540.2013 .820715$
Tran, A., K.K. Nkongolo, M. Mehes-Smith, R. Narendrula and G. Spiers et al., 2014. Heavy metal analysis in red oak (Quercus rubra) populations from a mining region in northern Ontario (Canada): Effect of soil liming and analysis of genetic variation. Am. J. Environ. Sci., 10: 363-373.

DOI: $10.3844 /$ ajessp.2014.363.373

van Elsas, J.D., G. Frois-Duarte, A. Keijzer-Wolters and E. Smit, 2000. Analysis of the dynamics of fungal communities in soil via fungal-specific PCR of soil DNA followed by denaturing gradient gel electrophoresis. J. Microbiol. Meth., 43: 133-151. DOI: $10.1016 / \mathrm{S} 0167-7012(00) 00212-8$

Watanabe, T., 2002. Pictorial Atlas of Soil and Seed Fungi: Morphologies of Cultured Fungi and Key to Species. 2nd. Edn., CRC Press, Florida, pp: 504.

Weyman-Kaczmarkowa, W. and Z. Pedziwilk, 2000. The development of fungi as affected by $\mathrm{pH}$ and type of soil, in relation to the occurrence of bacteria and soil fungistatic activity. Microbiol. Res., 155: 107-112. PMID: 10950193

Winterhalder, K., 1996. Environmental degradation and rehabilitation of the landscape around Sudbury, a major mining and smelting area. Environ Rev., 4: 185-224. DOI: 10.1139/a96-011

Yiqi, L. and X. Zhou, 2006. Soil Respiration and the Environment. 1st Edn., Elsevier Academic Press, Amsterdam, ISBN-10: 0120887827, pp: 316.

Zycha, H. and R. Siepmann, 1970. The Mucorales: A Description of all Genera and Species of this Group of Molds. 1st Edn., Lubrecht and Cramer Limited, West Germany, pp: 355. 